\title{
The Butterfly House
}

\author{
Carla Bobadilla
}

In Vienna's first district, the historical centre of the city, between the National Library, the Government Palace and the Opera, is the Butterfly House. It is located in the Burggarten, the emperor's garden, where Emperor Franz Joseph I and his wife Elisabeth would take walks during their leisure time. In 1901, a modernist-style greenhouse designed by the architect Friedrich Ohmann was built there to serve as a private royal garden. Within this space, the royal family and especially Franz Joseph I himself spent time caring for and contemplating "exotic" vegetation brought to Vienna throughout different expeditions and famous discovery voyages carried out by scientists in Europe during the eighteenth and nineteenth centuries.

During the 1990s, owing to a structural deterioration, the greenhouse underwent renovation works, which coincided with the need to relocate Schönbrunn's Butterfly House. After the relocation and renovation, in 1997 the use and purpose of the greenhouse was reconsidered and adapted to the new needs of the contemporary, progressive city of Vienna. At this time, the Butterfly House began operating as we know it today: a place where around forty different types of butterflies collected from various tropical regions of the planet live and reproduce, one of the most unique tourist attractions in the city of Vienna. 
The environment necessary for the life and reproduction of the butterflies - heat, humidity and a characteristic smell, with "exotic" plants and decorations - creates an effect of a journey through time and space for the visitors. In such an environment visitors feel as if they are topographically transported to other, more southern, latitudes. This greenhouse, like many others of its kind scattered throughout Europe, is categorized as a palm house, Palmenhaus. This concept is historically rooted in the imperial need to collect and store exotic items from research journeys to the colonies in the nineteenth and twentieth centuries. These trips were intended to discover regions not yet seen by European eyes, but they also had a purely scientific aim of collecting, cataloguing and naming the "new" species (Lack 2015: 26).

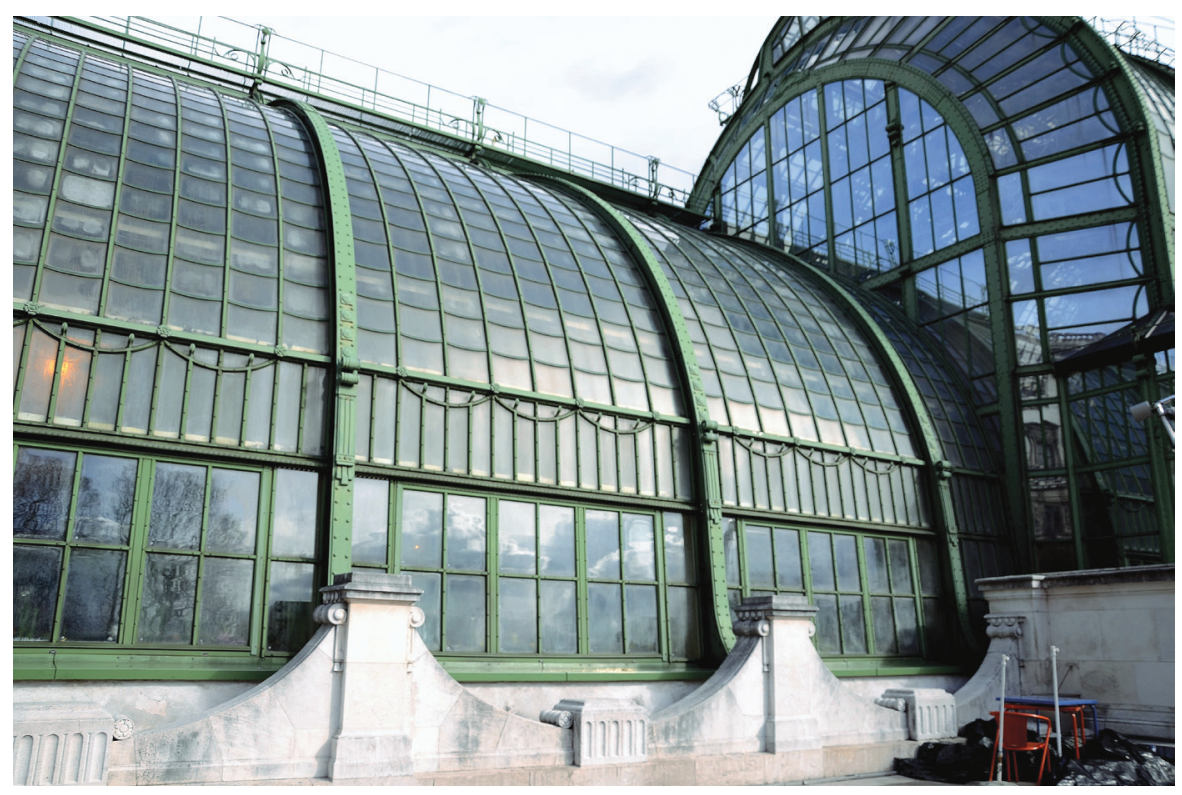

Figure 1: The Butterfly House. Carla Bobadilla, 2017. 


\section{Felipe Lettersten, Son of a Family of European Immigrants in Lima}

Within the midst of the copious vegeta tion and butterfly spectacle, visitors can find four fibreglass figures, which represent members of a family of indigenous people from the Amazon. Each character plays a role: the mother suckles a baby, the father hunts, the young man and the girl watch. Immersed among the tropical vegetation in the space and together with other elements such as fake trunks and plastic flowers, the figures fulfil the mission of "decorating" and "embellishing" the site, conferring it an even more "exotic" flair characteristic of the Amazon environment.

The fibreglass sculptures were made from plaster models taken directly from the bodies of inhabitants of the Amazon by the Swedish-Peruvian artist Felipe Lettersten (1957-2003). At the end of the 1980s, Lettersten began a trip on a double-decker steamboat, in the style of Fitzcarraldo (Herzog 1982). He sailed the rivers of the Amazon to "collect" materials and as an inspiration for his artistic work, justifying it with the motivation to preserve an image of indigenous peoples whom he considered in danger of extinction. During this voyage, he collected samples for what, in the framework of his travelling exhibitions around Europe, he called "indigenous hyperrealism".

Lettersten grew up in Lima as the son of a Swedish immigrant family. After finishing high school studies in Peru, he visited several art schools in Europe. The years he spent in Florence studying sculpture were particularly formative for his artistic career. As a development of his artistic practice, he championed the idea of portraying living bodies through the use of plaster. According to him, this method was the closest to an objective copy, and its use served the purpose of safeguarding both the integrity and the cultural heritage of indigenous peoples. Through this "artistic" 
gesture, he wanted to call attention from both local authorities and international organizations (Brooks 1991).

Lettersten was a gentle person with an extravagant appearance, complemented by his long, curly blond hair. He spoke the Quechua language, which he learned from the maids in his family home in Lima. These personal characteristics, together with the innovative artistic techniques that he used, helped him to facilitate encounters with indigenous communities, whose members offered themselves as models for free. Lettersten completed a series of sculptures out of direct plaster moulds, some of which were sent back to the communities from which the moulds were taken as a form of compensation.

As his artistic production advanced, his voyages became more frequent and his interest in sculpture proliferated. Lettersten managed to finish more than 230 bronze sculptures, of which he created copies in fibreglass. They are now distributed in various museums and archaeological sites in Latin America. Some of them came to Europe in the form of travelling exhibitions. We can still find four of them today in the Butterfly House in Vienna. The sculptures were acquired as a result of the friendship between the Butterfly House manager, Stephen A. Fried, and Lettersten, who offered the sculptures as a gift, but only if they would be permanently exhibited in the space.

\section{The Sculptures and the Problem that Their Decontextualization Implies}

Today the Butterfly House is visited daily by hundreds of tourists, who along with curiosity about the city's history are attracted to the idea of a place located in the middle of Vienna where five hundred living butterflies of multiple sizes and colours flutter in 
the air. ${ }^{1}$ At the same time, the place is also frequented by Viennese locals: families, primary schools and kindergartens go there to observe and immerse themselves in the imperial past of their own country and/or their country of residence. In doing so, the visitors become part of a tacit educational process through which they accept "the exotic" - the butterflies, the vegetation and therefore the sculptures - as an implicit and constituent part of their cultural heritage. In this context, the relationship to "the Other" becomes problematic, especially when some of these visitors share the same cultural origin as those portrayed in the sculptures. Families of ethnic immigrants from the Amazon region, in particular, observe their countrymen transformed into sculptures and condemned to serve as decorations in a place that aims to deliver values about the cultural heritage of the country where they currently reside and where their future descendants will probably live.

What can a girl, the daughter of Peruvian immigrants, think when she sees that her "ancestors" have been transformed into sculptures and are located in such a prominent place in the city, while their anonymity, owing to a lack of explanation, has left them without a voice and therefore without a history?

\section{From Representation to Deconstruction of the Image}

In the artistic research project "Österreichs kulturelles Erbe" I suggest that many places create and sustain a differentiated perspective on who the "others" are and the place that these others "should" occupy in both the past and the present history of Austria - be it the National History Museum and its collection, traditional products such as Meinl Coffee and its characteristic logo, or the Butterfly House with its sculptures of indigenous peoples.

1 More Information at: http://www.schmetterlinghaus.at/en/our-butterflies. 
Figure 2, Figure 3 and Figure 4:

From the series "Without our History".

Carla Bobadilla, 2017.

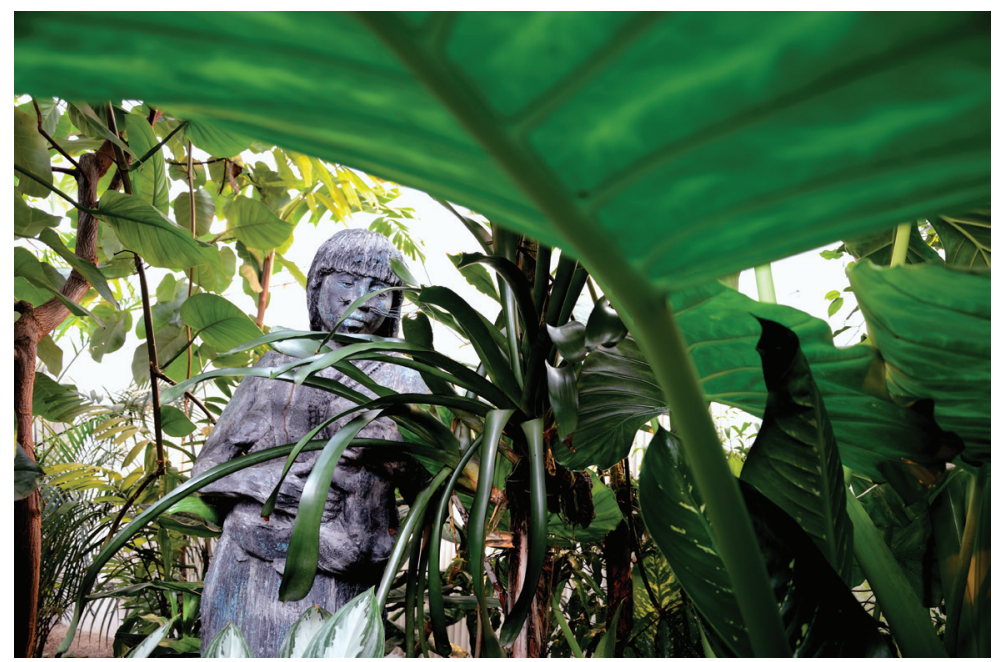

Figure 2

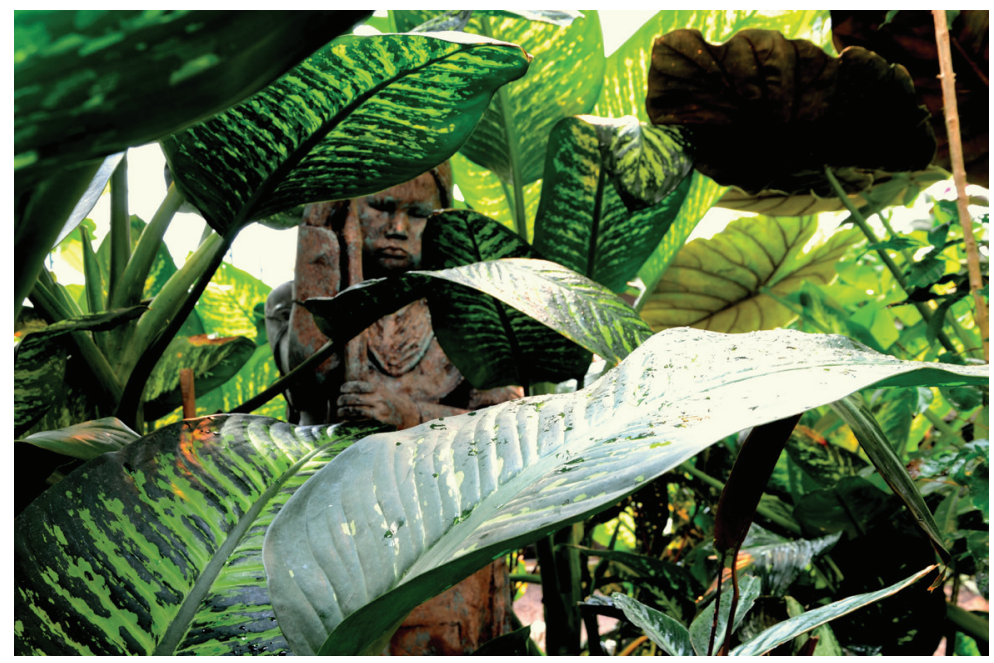

Figure 3 


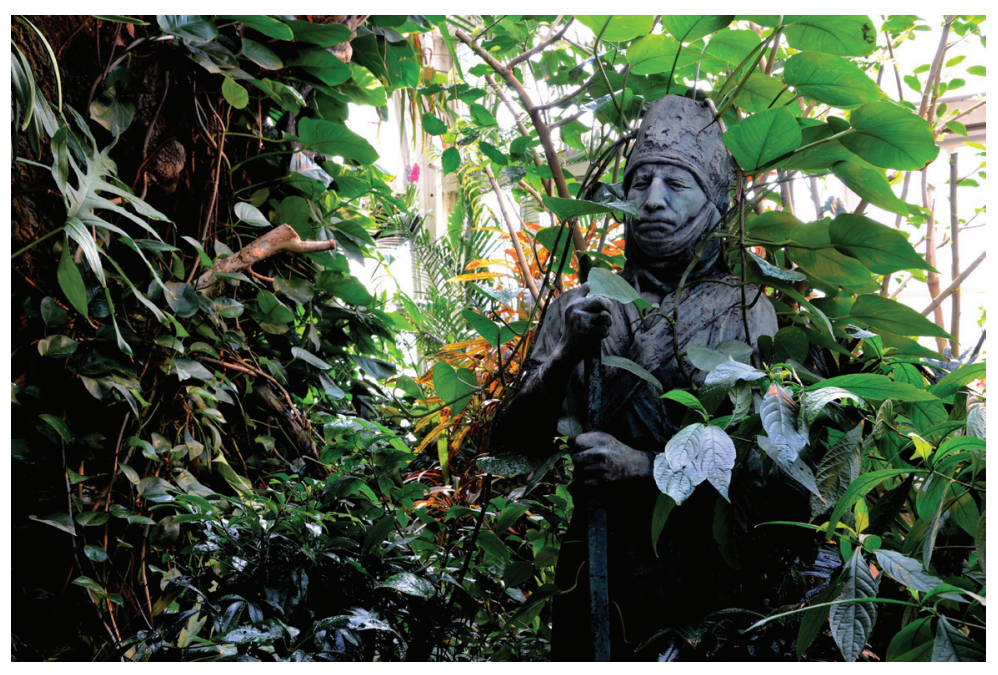

Figure 4

In 2016, I began a photography series intended to document places in Vienna where this contestable concept of cultural heritage can be witnessed. These photographs will serve in some cases as archival material, and in others as the first part of a process of analysis and deconstruction.

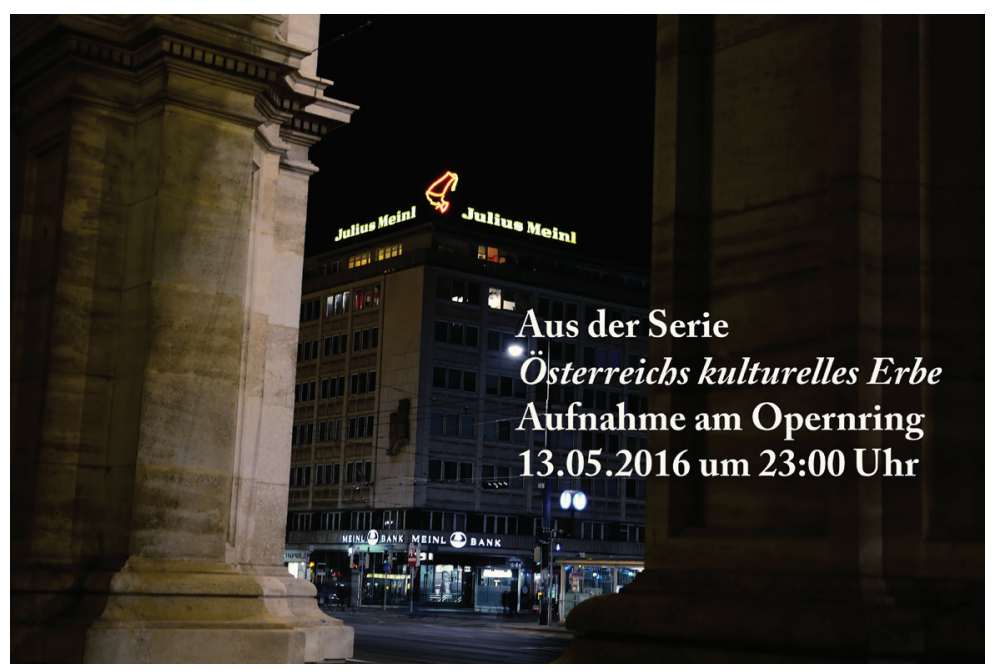

Figure 5:

From the series "Austrian Cultural Heritage". Julius Meinl. Carla Bobadilla, 2016. 
Figure 6: From the series "Austrian Cultural Heritage". NHM. Carla Bobadilla, 2017.

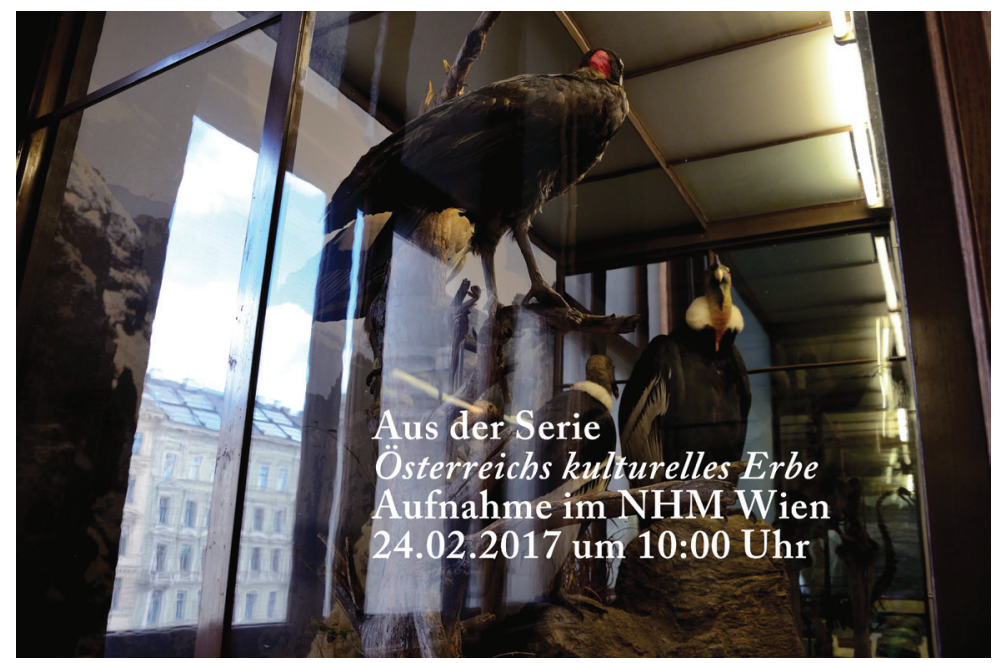

Figure 7:

From the series

"Austrian

Cultural

Heritage".

Butterfly House.

Carla Bobadilla,

2017.

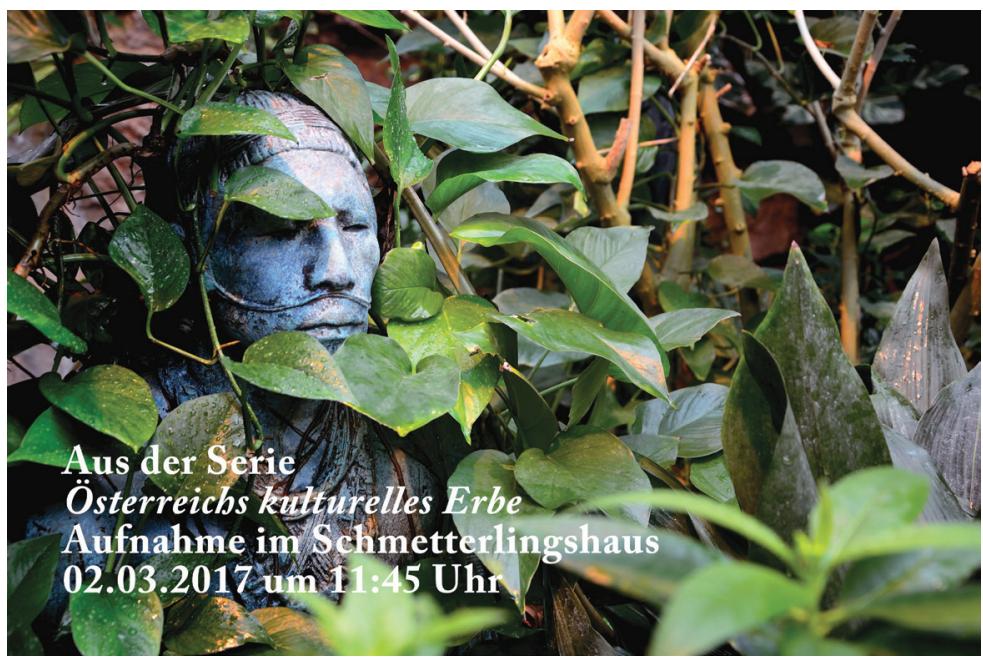


"The Walk as a Collective Method of Unlearning" was a project realized in the framework of the exhibition "Experimental Arrangement of Acting Unruly, Collective Forms of Exchanging Views on Emancipatory Strategies and Alliances of Solidarity" in 2017. This invitation gave me the chance to apply this method to question some places I discovered in my recent research.

By using the format of the collective walk, we invited a group of people, mainly adults, to the Butterfly House. We stopped at the entrance to tell the story of the origin of the sculptures. After that, we recited the list of the names of indigenous communities that were portrayed by Felipe Lettersten during his travels through the Amazonian rivers in the 1990s.

Yanomami, Parakanas, Araras, Orejones, Huitoto, Bora, Yahua, Aguarunas, Shipibos, Campas, Quechuas, Cashinahuas, Yaninahuas and Huarayos.

Along with this, we gave the group photographs of the four figures located inside the greenhouse, mounted on a piece of cardboard. ${ }^{3}$

The third element of this intervention was a live reading of a poem composed of four words and created by the writer and activist Vlatka Frketić, who was also part of the exhibition and participated in the process of creating the performance.

The poem reads:

2 Exhibition curated by Elke Smodić in the IG Gallery Bildende Kunst. http://www.igbildendekunst.at/kunst/programm-2017/versuchsanordnung-widerspenstigen-handelns.htm.

3 This technique has been used by the Swiss artist Thomas Hirschhorn, among others, for installations in public space. 


\section{WER HAT WAS DAVON \\ [who takes advantage of this]}

WER HAT WAS DAVON questions who benefits from these figures being in this space, without a voice and without a proper story that explains their origin.

The words were repeated by the public in multiple variations, by changing the order of the words and reciting them all together.

Not only did the collective walk help us to understand the role of such places within the city; it also highlighted the importance for the artist or collective work of taking responsibility to engage critically with those modes of representation in urban space. By joining our voices in unison, we were able to experience the strength of activism as an instrument of social transformation.

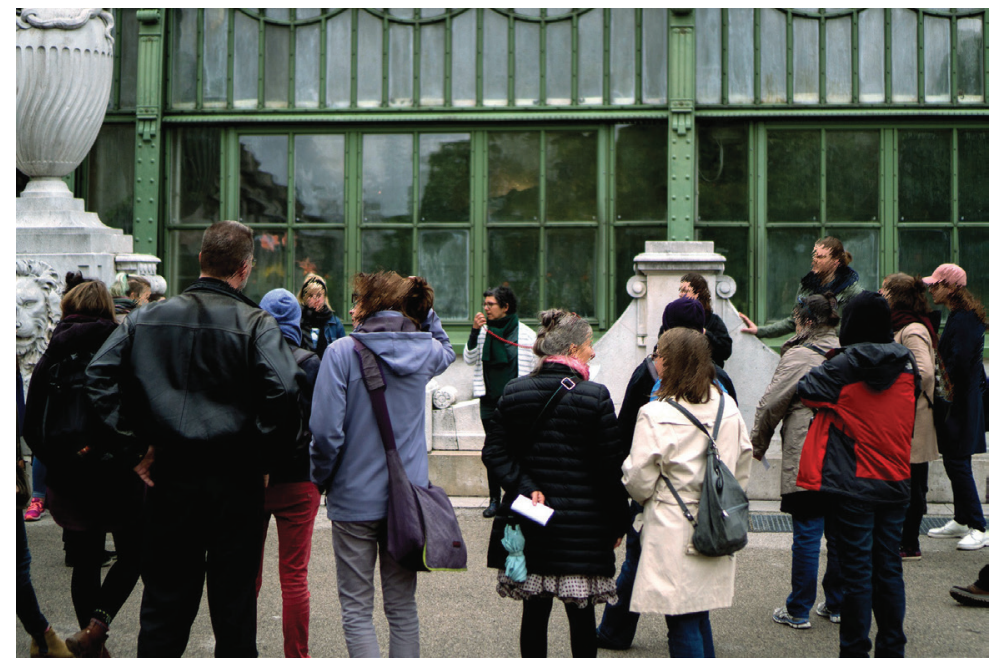

Figure 8 
Figure 8, Figure 9 and Figure 10:

Documentation of "The Walk as a

Collective Method of Unlearning".

Marian Essl, 2017.

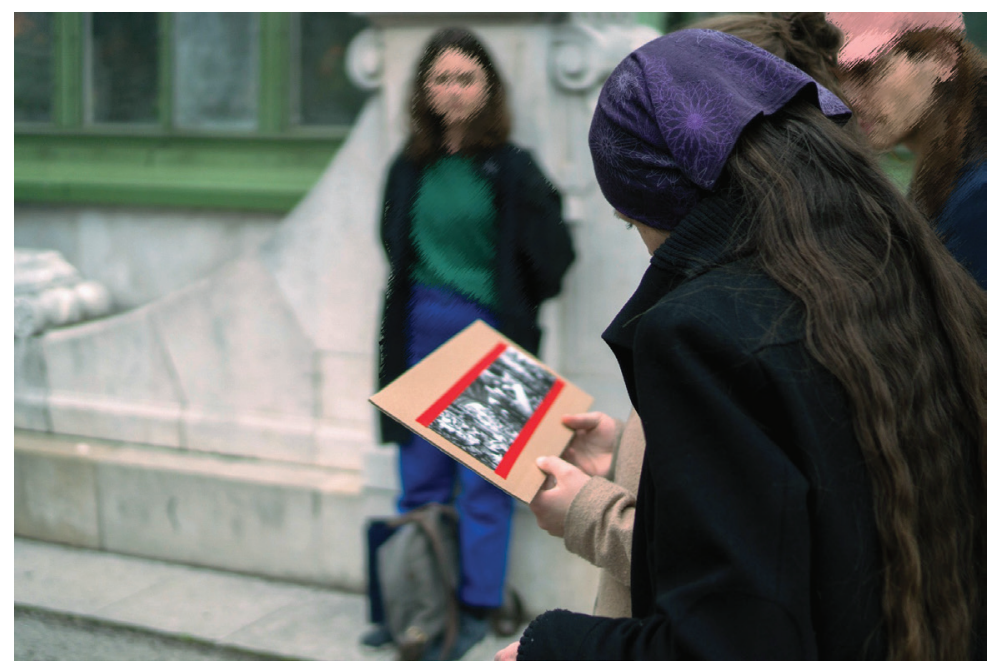

Figure 9

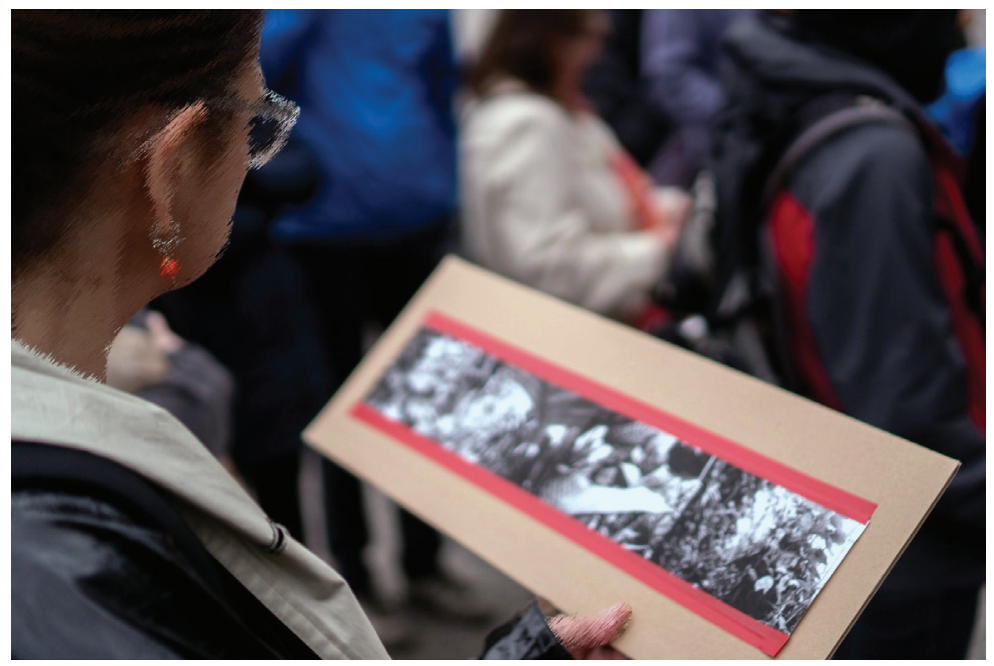

Figure 10 


\section{What Remains to Be Done}

The experiences collected during the three occasions on which we offered these walks and presented them to the public opened up questions about what might be the most appropriate artistic method to achieve an emancipatory "transformation" in public space (Mörsch 2009: 27). We recognized our walks as a starting point for developing a process of "un-learning" and rewriting official accounts (Castro Varela 2010: 236).

It is important that the figures in the Butterfly House are not removed and that they remain in place. Their presence offers the opportunity to engage in critical reflection on new and more appropriate ways of presenting and contextualizing both ethnological objects in museums in the city and artistic representations like them. There is a colonial history that we cannot erase, but that we can correct. We are part of this history and it is in our hands to question it and offer new possible answers.

As a future project and continuation of this one, we have planned a permanent artistic intervention both inside and outside the space. Ideally, the history of the origin of the sculpture figures would be rendered visible to everyone who visits the Butterfly House. This intervention could be accompanied by an educational programme, aimed at young audiences like primary schools and kindergartens. In this way, the work "Österreichs kulturelles Erbe" would not be confined to "denouncing" a fact by documenting it through photography, but would also turn it into an exercise of deconstruction through a permanent on-site intervention.

CARLA BOBADILLA is a visual artist affiliated with the Academy of Fine Arts, Vienna. She can be reached at office@carlabobadilla.at. 


\section{References}

Brooks, James. 1991. "Sculptor Preserves Amazon Images". The New York Times, 15 July. Accessed at https://www.nytimes. com/1991/07/15/arts/sculptor-preserves-amazon-images.html. Castro Varela, María do Mar. 2010. "Failure as Success". In Sketches of Migration. Postcolonial Enmeshments Antiracist Construction Work, pp. 229-240n. Edited by Achola, Bobadilla, Dimitrova, Güreş and del Sordo. Vienna: Löcker.

Herzog, Werner. 1982. Fitzcarraldo. Feature film.

Lack, Walter. 2015. “The World of Palm. Carl Friedrich Philipp von Martius and His Historia naturalis palmarum". In The Book of Palms. Cologne: Taschen.

Mörsch, Carmen and Research Team Editors documenta 12 Education. 2009. "A Crossroads of Four Discourses: documenta 12 Gallery Education in between Affirmation, Reproduction, Deconstruction and Transformation". In documenta 12 Education. Between Critical Practice and Visitors Services. Result of a Research Project, pp. 9-31. Zurich: Diaphanes. 